\title{
Alkvin iz Yorka: Naloge za ostrenje mladega uma
}

\author{
Prevod Rok Kuntner
}

Karel Veliki si je kot vladar enotne frankovske države med drugim prizadeval za korenito prenovo šolskega sistema. Njegov namen je bil izobraziti in usposobiti državni aparat, ki bi učinkovito vodil tako veliko državo. Da bi udejanjil svoj program, je na dvor, ki se je za časa njegove vladavine ustalil v Aachnu, povabil najvidnejše evropske učenjake svojega časa, ki so sprožili prvi intelektualni in civilizacijski preporod v samem srcu srednjega veka, znan pod nekoliko spornim imenom karolinška renesansa. Med povabljenimi učenjaki so bili Pavel Diakon, Teodulf iz Orléansa, Einhard, Angilbert, Peter iz Pise, Alkvin iz Yorka idr. Slednji se je kot dvorni šolnik tako odlikoval, da je v očeh sodobnikov že kmalu nastopal kot srce in duša dvorne šole, ki je zato postala znana pod imenom Schola magistri Albini. ${ }^{1}$ Šola je bila namenjena izobraževanju kraljeve družine, plemstva in duhovščine. Poleg upravnika dvorne šole je bil Alkvinu zaupan tudi položaj kraljevega svetovalca $\mathrm{v}$ raznovrstnih zadevah, predvsem pa $\mathrm{v}$ tistih povezanih $\mathrm{z}$ reformo šolskega sistema. ${ }^{2}$ Alkvinov učni načrt je temeljil na sedmih svobodnih umetnostih (lat. septem artes liberales). Takšen učni načrt, ki je vključeval slovnico, logiko oz. dialektiko in retoriko (trivij) ter aritmetiko, geometrijo, glasbo in astronomijo (kvadrivij), je služil pridobitvi osnovnih znanj, ki so bila potrebna za poglobljeno branje in razumevanje

1 Alkvinovo ime se v virih najpogosteje pojavlja v treh različicah: Alc(h)uinus, Ealhwine in Albinus. Pri slednjem ne gre za različico avtorjevega krstnega imena, ampak za latinsko ime, ki ga je avtor posvojil zaradi glasovne podobnosti s krstnim imenom. V skladu s konvencijo kroga izobražencev na Karlovem dvoru je Alkvin rad uporabljal tudi priimek Flak (lat. Flaccus) kot navezavo na avgustejskega pesnika Kvinta Horacija Flaka.

2 Po njegovem nasvetu je bilo sestavljeno eno najpomembnejših poglavij Kapitularija (Admonitio generalis), ki je predpisovalo prenovo šolskega sistema. Nosilci te prenove so bili samostani in cerkvene šole, ki so v tistem času edini razpolagali s starimi knjižnimi fondi. Mnogo samostanov je zato kralj podaril v last svojim dvornim učenjakom. Alkvin je najprej dobil opatiji Ferrière in Staint-Loup v mestu Troyes, kasneje pa še samostan Saint-Martin v Toursu. 
Svetega pisma. Obvladovanje aritmetike je bilo nujno za razumevanje pomena števil, ki se pojavljajo v Svetem pismu, in za t. i. computus, metodo, ki je bila v rabi za izračun datuma krščanske velike noči, o čemer se je v teku srednjega veka veliko razpravljalo.

Naloge za ostrenje mladega uma (lat. Propositiones ad acuendos iuvenes) nam nudijo vpogled $\mathrm{v}$ pouk aritmetike in geometrije $\mathrm{v}$ Alkvinovi šoli, pa tudi $\mathrm{v}$ drugih samostanskih in cerkvenih šolah širom po frankovski državi. Naloge, ki vsebujejo 56 problemov z rešitvami, so najstarejša zbirka problemov iz razvedrilne matematike $v$ latinščini in tako tudi najstarejše pričevanje o rabi matematike v pedagoške namene v Evropi. Najstarejšo omembo Nalog najdemo v 75. pismu Alkvinove korespondence s Karlom Velikim, ki ga datirajo v leto 799 ali 800 . V pismu lahko preberemo med drugim tudi odlomek, ki se glasi: $»$ Misi excellentiae vestrae [...] aliquas figuras arithmeticae subtilitatis, laetitiae causa.« (»Vaši visokosti sem v razvedrilo poslal [...] nekaj oblik aritmetične ostrine. «) Omenjene figurae sicer žal niso vključene v pismo, vendar pa je zelo verjetno, da gre za zbirko Propositiones ad acuendos iuvenes, ki so se v večini rokopisov ohranile pod Alkvinovim imenom. ${ }^{3}$

Naloge so dragocene zlasti zato, ker nam do neke mere ponujajo vpogled $\mathrm{v}$ načine soočanja $\mathrm{z}$ računskimi in matematičnimi problemi praktične narave $\mathrm{v}$ skladu s takrat dostopnim znanjem in $\mathrm{z}$ razpoložljivimi pripomočki. Velike težave je srednjeveškemu reševalcu povzročalo že osnovno operiranje $z$ velikimi števili, saj sistem rimskih številk ni omogočal podpisovanja. Tako srednjeveškemu kot modernemu reševalcu včasih več težav kot reševanje samih problemov povzroča razumevanje rešitev, ki sicer podajajo postopek reševanja, vendar pogosto ne na način, ki bi bil za reševalca $\mathrm{v}$ zadregi koristen (od podatkov preko postopka do rezultata), kajti že v postopku, ki ga avtor ne pojasni, so podane pravilne vrednosti neznanke, ki izhajajo iz avtorjevega predhodnega poznavanja rezultata (gl. npr. rešitev naloge 2). Z vidika modernega reševalca, ki je pri matematiki vajen računanja $\mathrm{z}$ natančnimi vrednostmi in ne s približki, se med drugim kot posebej problematični kažejo načini računanja ploščin nepravilnih n-kotnikov. Alkvin z uporabo nenatančnih metod za poenostavljanje likov in približnih formul pogosto pride do rezultata, ki je tako nenatančen, da ni več praktično uporaben (gl. npr. rešitev naloge 27).

\section{ZGRADBA IN TIPI NALOG}

Vse naloge iz zbirke imajo sledečo zgradbo: (1) naslov, (2) predstavitev problema in izjava, (3) nagovor in vzpodbuda reševalcu ter (4) rešitev. Iz takšne zgradbe in iz realij, ki so nam znane iz obdobja nastanka zbirke, lahko

3 Nekateri rokopisi zbirko pripisujejo Bedu Častitljivemu. 
sklepamo, da so bile naloge namenjene glasnemu branju in da so bile učencem narekovane, ti pa so si podatke zapisovali na papirus, drevesno lubje ali pergament in nalogo rešili. Naloge, ki se pojavljajo v zbirki, sodijo v kategorijo razvedrilne matematike, najpogostejši tipi nalog pa so naslednji:4

a) Večji del aritmetičnih nalog (13) spada med linearne probleme $z$ eno neznanko. Med njimi so problemi o številu ali količini $(2-4,40,45,48)$ in o starosti $(36,44)$. Te naloge vselej vodijo na linearno enačbo oblike $n \mathrm{x}+p=100$, pri čemer je $n$ seštevek določenih racionalnih števil, $p$ pa je naravno število ali 0 . Takšen tip nalog pogosto srečujemo že v najstarejših egipčanskih, indijskih in arabskih besedilih. Nadalje sodijo v to skupino tudi t. i. problemi o gibanju, ki pa so v Nalogah skromno zastopani: mednje nedvomno sodi naloga 26, pogojno pa bi jim lahko priključili tudi nalogo 1. Preostale štiri naloge $(7,8,37,52)$ so manj tipične predstavnice te skupine.

b) Med linearne probleme $z$ več neznankami sodi devet aritmetičnih nalog $(5,16,32,33,33 a, 34,38,39,47)$. Problem 16 je najosnovnejši, toda značilen predstavnik svoje podvrste t. i. nalog dajanja in jemanja. Ta podvrsta problemov z več neznankami je tipična za probleme grške algebre, ki pa jo kasneje najdemo tudi v indijskih, arabskih in ostalih vzhodnjaških zbirkah nalog. Ostali problemi tega tipa sodijo v podvrsto razdelitve računa.

c) Na probleme $z$ aritmetičnimi ali geometrijskimi zaporedji in vrstami naletimo v vseh visokih kulturah od najstarejših obdobij. Najstarejši primer geometrijske vrste je zabeležen na papirusu Rhind (zap. št. 79), naloge takega tipa pa so zgodaj izpričane tudi na Kitajskem. V naši zbirki najdemo tri probleme tega tipa: naloge 13, 41 in 42 .

d) Med razvrstitvene probleme sodi skupno enajst nalog iz naše zbirke. Mednje štejemo slavne probleme prevoza čez reko (17-20), za katere se zdi, da se prvič pojavijo prav v Alkvinovih Nalogah. Najslavnejši problem prevoza čez reko, ki je postal kasneje zelo priljubljen in se ga pogosto rešuje še danes, je gotovo naloga o volku, kozi in zeljni glavi. Ta naloga je dobila skozi zgodovino mnogo različnih podob, ideja in metoda reševanja pa ostajata vselej ista. V Angliji je, denimo, najbolj znana različica The fox, goose and bag of beans puzzle, pri nas pa $\mathrm{v}$ problemu najpogosteje nastopajo protagonisti iz izvirnika: volk, zajec in zeljna glava.

e) Dvanajst nalog, kar je skoraj četrtina zbirke, sodi med probleme računske geometrije $(9,10,21-25,27-31)$. Ta tip matematičnih problemov je izredno pogost tudi v drugih zbirkah nalog iz razvedrilne matematike,

$4 \mathrm{Za}$ obširnejšo študijo tipov nalog gl. M. Folkerts, izd., Die älteste mathematische Aufgabensammlung in lateinischer Sprache: Die Alkuin zugeschriebenen Propositiones ad acuendos iuvenes: Überlieferung, Inhalt, Kritische Edition (Dunaj: Springer, 1978), 34-41, in R. Franci, prev., Giochi matematici alla corte di Carlomagno: Problemi per rendere acuta la mente dei giovani (Pisa: ETS, 2005), 18-23. 
vendar se problemi računske geometrije v naši zbirki od drugih razlikujejo $\mathrm{v}$ tem, da za razreševanje trikotnikov ne uporabljajo Pitagorovega izreka in izrekov o podobnosti trikotnikov. Način reševanja teh nalog kaže na to, da je njihov izvor smiselno iskati v tradiciji rimskih zemljemercev. ${ }^{5}$ $S$ podobnimi problemi smo soočeni že pri Heronu, v 5. knjigi Kolumelove De re rustica in v besedilih iz zbirke Corpus agrimensorum.

\section{MERSKE ENOTE 6}

\section{Dolžinske mere}

1 palec (lat. uncia $)=\frac{1}{12}$ čevlja $(\doteq 2,5 \mathrm{~cm})$

1 čevelj (lat. pes $)=12$ palcev $(\doteq 30 \mathrm{~cm})$

1 vatel (lat. cubitum $)=1 \frac{1}{2}$ čevlja $(\doteq 0,5 \mathrm{~m})^{1}$

1 korak (lat. passus) $=5$ čevljev $(\doteq 1,5 \mathrm{~m})$

1 pertika (lat. pertica) $=10$ sežnjev $(\doteq 15 \mathrm{~m})$

1 liga $($ lat. leuva $)=1500$ korakov $(\doteq 2,25 \mathrm{~km})$

\section{Ploščinske mere}

1 kvadratni čevelj (lat. pes)

1 kvadratna pertika (lat. pertica)

1 aripen (lat. aripennis) $=$

144 kvadratnih pertik $\left(\doteq 28,76 \mathrm{a} \doteq 2876 \mathrm{~m}^{2}\right)$
Prostorninske mere

1 polič (lat. sextarius $) \doteq 0,541$

1 mer $($ lat. merus $)=\frac{1}{6}$ poliča $(\doteq 0,091 \doteq 1 \mathrm{dl})$

1 mernik (lat. modius $)=24$ poličev $(\doteq 12,961)$

1 metrum (lat. metrum) $=48$ poličev $(\doteq 25,92 \mathrm{l})$

1 metreta (lat. metreta $)=3$ merniki $(\doteq 38,88 \mathrm{l})$

\section{Uteži in denar}

1 talent (lat. talentum) $=75$ funtov

1 funt (lat. libra) $=20$ solidov $=240$ denarijev

1 solid/zlatnik (lat. solidus) $=12$ denarijev

1 funt (lat. libra) $=12$ unč (lat. uncia)

5 Zemljemerci (lat. agrimensores ali gromatici) so bili nekakšni nadzorniki državnih zemljišč, ki so se ukvarjali z izmero, kartografsko ponazoritvijo in določanjem poljedelskih površin. Nekateri zemljemerci so svoje tehnike tudi beležili: najzgodnejši tak avtor je bil Sekst Julij Frontin iz 1. stol. po Kr. Večino nalog iz naše zbirke se da uspešno rešiti z metodami, ki so jih pri svojem delu uporabljali rimski zemljemerci.

6 Navedene vrednosti veljajo za čas in okolje, v katerem so nastale Naloge, ter kažejo odklon od tistih, ki se pod enakimi imeni pojavljajo v antiki. Antične in srednjeveške uteži in mere namreč niso bile normirane tako kot danes, ampak so bile podvržene časovnim in regionalnim nihanjem. 


\section{ZAČETEK NALOG ZA OSTRENJE MLADEGA UMA7}

\section{NALOGA O POLŽU}

Lastovica $^{8}$ je polža povabila na kosilo eno ${ }^{9}$ ligo stran. Ta pa v enem dnevu ni mogel prehoditi več kot dolžine enega palca. Naj pove, kdor želi, koliko dni bo naš polž porabil za pot do kosila.

Rešitev o polžu:

V eni ligi je 1500 korakov, kar je 7500 čevljev oziroma 90000 palcev. Kolikor pa je bilo palcev, toliko je bilo dni, ki skupaj znesejo 246 let in 210 dni.

\section{NALOGA O MOŽU, KI SE JE SPREHAJAL PO CESTI}

Neki mož se je sprehajal po cesti in opazil ljudi, ki so mu prihajali naproti. Dejal jim je: »Želel bi, da bi vas bilo dvakrat toliko, kolikor vas je, pa še polovica polovice (tega števila) in ponovno polovica od te polovice. Tedaj bi vas bilo skupaj z menoj 100.« Naj pove, kdor želi, koliko je bilo ljudi, ki jih je videl na začetku.

\section{Rešitev:}

Tistih, ki jih je videl na začetku, je bilo 36. Dvakrat toliko je 72. Polovica polovice je 18. In polovica tega števila je 9 . Reci torej takole: $72+18$ znese 90 . Prištej 9, da dobiš 99. Dodaj govorca in imel jih boš $100 .^{10}$

\section{NALOGA O DVEH POPOTNIKIH, KI STA VIDELA ŠTORKLJE}

Dva človeka sta se sprehajala po cesti in opazila štorklje. Rekla sta si: »Koliko jih je? « Razpravljajoč o številu sta dejala: »Če bi jih bilo dvakrat toliko in še trikrat toliko in polovica tretjine ter povrhu še 2 dodatni, bi jih bilo 100.« Naj pove, kdor more, koliko štorkelj sta videla na začetku.

\section{Rešitev o štorkljah:}

28 in 28 in še tretjič toliko znese 84. Polovica tretjine (sc. od 84) je 14. Vseh skupaj je 98. Dodamo 2 in dobimo $100 .{ }^{11}$

7 Prevod sledi latinskemu besedilu v kritični izdaji Folkerts, Die älteste mathematische Aufgabensammlung. Pri nalogah, v katerih sta opisana dva postopka za rešitev, je v prevod vključen samo po moji presoji boljši postopek. - Opombe so deloma povzete po spremni študiji v zgoraj citirani kritični izdaji in po komentarjih v Franci, Alcuino di York. Številčenje nalog se ujema s Folkertsovo kritično izdajo (gl. zgoraj). Naloge pod zaporednimi številkami 11a, 11b in 33a predstavljajo dodatke v rokopisih Nalog, pripisanih Bedu Častitljivemu.

8 Lastovica (lat. hirundo); možno je, da gre za pijavko (lat. hirudo). Rokopisi se na tem mestu ne ujemajo.

9 Glede zapisovanja števnikov se v prevodu držim sledečih pravil: (1) glavne števnike se zapisuje s števili, razen v primerih, kjer se pojavljajo v odvisnih sklonih, npr. "mojih treh sinov"; (2) vrstilne števnike se zapisuje z besedo; (3) glavni števnik 1 (ena) se zapisuje z besedo ali izpušča, npr. "en zlatnik" ali "zlatnik"; (4) v nekaterih besedilnih nalogah in v premih govorih znotraj posameznih nalog se iz estetskih ali praktičnih razlogov kljub pravilu pod točko (1) tudi glavne števnike zapisuje $\mathrm{z}$ besedo; (5) v besedilnih nalogah se deleže zapisuje z besedo, $\mathrm{v}$ rešitvah nalog, kjer se deleži seštevajo, pa z ulomki (npr. $\frac{1}{2}+1 \frac{1}{2}$ ).

10 Linearni problem $\mathrm{z}$ eno neznanko (gl. tipi nalog), ki se ga reši $\mathrm{z}$ enačbo $x+x+\frac{x}{2}+\frac{x}{4}+1=100$, pri čemer je x število ljudi, ki jih je govorec videl prihajati naproti, končna cifra 1 pa je govorec. Enačbo rešimo in dobimo pravilno rešitev $x=36$.

11 Linearni problem z eno neznanko (gl. tipi nalog) z nekoliko nejasno zastavljenim vprašanjem. Podobno kot 2., se ga reši z enačbo $x+x+x+\frac{x}{2}+2=100$, pri čemer je $\mathrm{x}$ število štorkelj. Enačbo rešimo in dobimo pravilno rešitev $x=28$. 


\section{NALOGA O ČLOVEKU IN KONJIH, KI SO SE PASLI NA POLJU}

Neki človek je videl konje, ki so se pasli na polju, in izrazil željo rekoč: »O, da bi bili moji in da bi vas bilo dvakrat toliko in še polovica polovice - tedaj bi se prav gotovo šopiril s 100 konji.« Naj razbere, kdor želi, koliko konjev je človek videl na paši.

Rešitev o konjih:

Na paši je bilo 40 konjev. Dvakrat toliko znese 80 . Če dodamo polovico polovice od tega (sc. od 80 ), to je 20 , dobimo $100 .^{12}$

\section{NALOGA O KUPCU S 100 DENARIJI}

Neki kupec je dejal: »Za 100 denarijev želim kupiti 100 prašičev, in sicer tako, da dam za zrelega merjasca 10 denarijev, za svinjo 5 denarijev, za 2 prašička pa en denarij.« Naj pove, kdor razume, koliko merjascev, koliko svinj in koliko prašičkov mora biti, da število vseh prašičev in vsota denarijev ne bosta niti večji niti manjši od 100 .

\section{Rešitev o kupcu:}

9 svinj in enega merjasca kupi s 55 denariji ter 80 prašičkov s 40 denariji. Glej, imaš 90 prašičev. Za preostalih 5 denarijev kupi 10 prašičkov in imel boš po številu 100 denarijev in 100 prašičev. $^{13}$

\section{NALOGA O DVEH TRGOVCIH, KI STA IMELA 100 ZLATNIKOV}

Bila sta dva trgovca, ki sta imela skupaj 100 zlatnikov, s katerimi sta kupila prašiče. Za 2 zlatnika sta kupila 5 prašičev, ki sta jih hotela porediti, jih ponovno prodati ter imeti dobiček. Ker pa sta opazila, da ni pravi čas za rejenje prašičev, sama pa jih v času zime nista mogla pasti, sta jih poskusila prodati in imeti dobiček. Na njuno žalost nista bila uspešna, saj jih nista mogla prodati za več kot toliko, za kolikor sta jih kupila, to je 5 prašičev za 2 zlatnika. Ko sta to spoznala, sta eden drugemu dejala: »Razdeliva si jih!« Razdelila sta si jih in jih prodala tako, kot sta jih kupila, ter imela dobiček. Naj pove, kdor more, koliko prašičev je bilo na začetku, in naj jih razdeli, proda ter ima dobiček, in sicer tako, kot bi ne bilo možno, če bi jih prodal skupaj.

12 Linearni problem $z$ eno neznanko (gl. tipi nalog), ki se ga reši $z$ enačbo $x+x+\frac{x}{2}=100$, pri čemer je $\mathrm{x}$ število konj na paši. Enačbo rešimo in dobimo pravilno rešitev $x=40$.

13 Gre za tip nalog, ki jih imenujemo problemi 100 ptic, med katere poleg naloge 5 sodita še nalogi 38 in 39. Naloge tega tipa sodijo $\mathrm{v}$ isto skupino kot problemi razdelitve živeža (gl. opombo $\mathrm{k}$ rešitvi naloge 32). Podana rešitev je točna, pot do rezultata pa le delno nakazana. Pogoji izjave se prevedejo v sistem dveh linearnih enačb s tremi neznankami, od katere se je treba ene znebiti: $x+y+z=100$ in $5 x+10 y+\frac{z}{2}=100$, to je $10 x+20 y+z=200$, pri čemer je x število svinj, y število merjascev in z število prašičkov. Sistem rešimo takole: (1) Iz prve enačbe izrazimo spremenljivko Z: $z=100-(x+y)$. (2) Enačbi odštejemo in dobimo $9 x+19 y=100$. (3) S poskušanjem ugotovimo vrednost spremenljivke y, ki mora biti zaradi narave problema takšna, da bo $100-19 y$ pozitivno celo število deljivo z 9. S serijo poskusov ugotovimo, da je lahko to samo $y=1$. (4) Vrednost y vstavimo v enačbo $9 x+19 y=100$ in dobimo $x=9$. (5) Nato vstavimo vrednosti $\mathrm{x}$ in $\mathrm{y} \mathrm{v}$ enačbo $z=100-(x+y)$ in dobimo $z=90$. Rešitev naloge je torej $x=9, y=1, z=90$. V tem primeru obstaja ena sama rešitev, vendar pa, kakor bomo videli v nadaljevanju, Alkvin eno samo rešitev poda tudi v primerih, kjer je teh več (prim. naloge 32-34). 
Rešitev o prašičih:

Na začetku je bilo 250 prašičev, ki sta jih kupila za 100 zlatnikov, kakor je bilo rečeno zgoraj, torej po 5 prašičev za 2 zlatnika. Kajti če pomnožiš $50 \times 5$ ali $5 \times 50$, dobiš 250 . Ko sta si jih razdelila, je vsak vzel 125 prašičev. Eden je prodal po 3 slabše prašiče za zlatnik, drugi pa po 2 boljša prašiča za zlatnik. Tako se je izšlo, da je tisti, ki je prodal slabše, od 120 prašičev iztržil 40 zlatnikov, tisti pa, ki je prodal boljše, 60 zlatnikov, kajti slabši so bili prodani po $30 \mathrm{za}$ 10 zlatnikov, boljši pa po 20 za 10 zlatnikov. In vsakemu od njiju je ostalo 5 prašičev, od katerih sta lahko imela 4 zlatnike in 2 denarija dobička. ${ }^{14}$

\section{NALOGA O KROŽNIKU, KI TEHTA 30 FUNTOV}

Imamo krožnik, ki tehta 30 funtov oziroma 600 solidov. V sebi ima zlato, srebro, medenino in kositer. Srebra ima trikrat toliko kot zlata, medenine trikrat toliko kot srebra in kositra trikrat toliko kot medenine. Naj pove, kdor more, koliko tehta vsaka pozamezna vrsta kovine v njem.

Rešitev o krožniku:

Zlato tehta 9 unč, ${ }^{15}$ srebro trikrat 9 unč, to sta 2 funta in 3 unče. Medenina tehta trikrat 2 funta in 3 unče, to je 6 funtov in 9 unč. Kositer tehta trikrat 6 funtov in 9 unč, to je 20 funtov in 3 unče. Če seštejemo 9 unč $+(2$ funta in 3 unče $)+(6$ funtov in 9 unč $)+(20$ funtov in 3 unče $)$, dobimo 30 funtov.

Še v solidih: Zlato tehta 15 solidov. Srebro trikrat 15 solidov, to je 45 solidov. Medenina trikrat 45 solidov, to je 135 solidov. Kositer trikrat 135 solidov, to je 405 solidov. Seštej 405+135+45+15 in dobil boš 600 solidov, kar je enako 30 funtov. $^{16}$

\section{NALOGA O KADI}

Kad, ki drži 100 metret oziroma 300 mernikov, iz nje pa vodijo 3 cevi, napolnimo do vrha. Skozi prvo cev odtekata tretjina in šestina, skozi drugo samo tretjina, skozi tretjo pa samo šestina vsebine kadi. Naj pove, kdor želi, koliko poličev odteka po vsaki od treh cevi.

Rešitev:

Skozi prvo cev odteka 3600, skozi drugo 2400, skozi tretjo pa 1200 poličev. ${ }^{17}$

14 Gre za paradoksalno rešitev problema, v katerem je treba določeno količino robe prodati za isto ceno, kot je bila kupljena, in imeti od kupčije dobiček. Naloga je smiselna samo, če se strinjamo s trditvijo, da smo 5 prašičev prodali za isto ceno (2 zlatnika) v obeh primerih: (a) 5 prašičev za dva zlatnika in (b) 3 prašiče slabše kvalitete za en zlatnik ter 2 prvorazredna prašiča za en zlatnik.

15 unča (lat. uncia) je enota, ki v svojem bistvu pomeni $\frac{1}{12}$ neke večje enote. Pri dolžinskih merah palec (lat. uncia) pomeni $\frac{1}{12}$ čevlja (lat.pes), pri utežnih ${ }^{12}$ merah pa pomeni unča (lat. uncia) $\frac{1}{12}$ funta (lat. libra). Za ostale mere in uteži gl. zgoraj poglavje Merske enote.

16 Predstavljeni sta dve rešitvi, $v$ prvi se računa $\mathrm{z}$ unčami in funti, $\mathrm{v}$ drugi s solidi (prim. Merske enote). Nalogo lahko rešimo z linearno enačbo z eno neznanko, in sicer tako, da vzamemo maso celotnega krožnika bodisi v unčah bodisi v solidih. Tukaj podajam samo rešitev v solidih: $x+3 x+9 x+27 x=600$, pri čemer je x masa zlata v solidih. Enačbo rešimo in dobimo $x=15$, kar je 15 solidov.

17 Če upoštevamo pretvorbo 1 metreta $=72$ poličev, ima vsebina kadi prostornino 7200 poličev. Tako po prvi cevi odteka $\left(\frac{1}{3}+\frac{1}{6}\right) \times 7200=\frac{7200}{2}=3600$ poličev, po drugi $\frac{1}{3} \times 7200=2400$ poličev in po tretji $\frac{1}{6} \times 7200=1200$ poličev. 


\section{NALOGA O OGRINJALU}

Imam blago, ki v dolžino meri 100, v širino pa 80 vatlov. Iz njega bi rad izdelal ogrinjalo, in sicer tako, da bi ga razrezal na kose, od katerih bi vsak v dolžino meril 5, v širino pa 4 vatle. Povej, prosim, ti, ki veš, koliko ogrinjal lahko dobimo iz tega blaga.

Rešitev:

Ena osemdesetina od 400 je 5 . Ena stotina je 4 . Če torej zmnožiš $80 \times 5$ ali $100 \times 4$, vselej dobiš 400 . Toliko bo tudi ogrinjal.

\section{NALOGA O PLATNU}

Imam kos platna, ki meri v dolžino 60, v širino pa 40 vatlov. Želim ga razrezati tako, da bo vsak kos $\mathrm{v}$ dolžino meril 6 , v širino pa 4 vatle in da bo tako zadostoval za izdelavo tunike. Pa naj pove, kdor želi, koliko tunik lahko dobimo iz tega platna.

Rešitev:

Ena desetina od 60 je 6, ena desetina od 40 pa je 4 . Če torej desetkrat vzameš eno desetino od 60 ali eno desetino od 40, dobiš 100 kosov dolgih 6 in širokih 4 vatle.

\section{NALOGA O DVEH MOŠKIH, OD KATERIH SE VSAK POROČI S} SESTRO DRUGEGA

Recimo, da se dva moška poročita vsak s sestro drugega. Povej, prosim, v kakšnem sorodstvenem razmerju bosta njuna sinova.

Rešitev te naloge:

Na primer: če se jaz poročim s sestro svojega prijatelja in on $\mathrm{z}$ mojo, potem pa ima vsak od naju sina, sem jaz torej sinu svoje sestre stric, ona pa mojemu sinu teta. In takšno je njuno sorodstvo. Moj sin in sin moje sestre bosta torej neke vrste bratranca.

11a. NALOGA O DVEH MOŠKIH, OD KATERIH SE VSAK POROČI S SESTRO DRUGEGA

Če se dva moška poročita vsak z materjo drugega, kakšno sorodstvo bo tedaj vezalo njuna sinova?

Rešitev:

Moj sin in sin moje matere sta stric in nečak.

\section{1b. NALOGA O OČETU, SINU, VDOVI IN NJENI HČERI}

Recimo, da se oče in sin poročita $\mathrm{z}$ zapuščeno ali vdovelo žensko in njeno hčerjo ter skleneta, da sin vzame mater, oče pa hčer. V kakšnem sorodstvenem razmerju, te sprašujem, bosta sinova, rojena iz njunih zakonov.

Rešitev:

Moj sin in sin mojega očeta sta eden drugemu stric in nečak. 


\section{NALOGA O NEKEM HIŠNEM GOSPODARJU IN NJEGOVIH} TREH SINOVIH

Neki hišni gospodar je na smrtni postelji svojim trem sinovom v dediščini zapustil 30 stekleničk: 10 polnih olja, 10 napol polnih in 10 praznih. Naj razdeli, kdor more, olje in stekleničke, tako da bo vsakemu od treh sinov pripadla enaka količina olja in enako število stekleničk.

Rešitev:

Imamo torej 3 sinove in 30 stekleničk: 10 polnih, 10 napol polnih in 10 praznih. Zmnoži $3 \times 10$, da dobiš 30 . Vsakemu od sinov pripade 10 stekleničk. Razdeli pa na 3 dele še olje, in sicer na sledeči način: prvemu daj 10 napol polnih stekleničk, drugemu in tretjemu pa vsakemu po 5 polnih in 5 praznih stekleničk. Tako bo razdelitev med 3 brate pravična tako v olju kot v stekleničkah. ${ }^{18}$

\section{NALOGA O KRALJU IN NJEGOVI VOJSKI}

Neki kralj je svojemu slugi ukazal, naj iz 30 utrdb nabere vojsko, in sicer tako, da v vsaki utrdbi nanovači toliko ljudi, kolikor jih je bil tja privedel. Prvo utrdbo je sluga obiskal sam, v drugo je prišel v dvoje, v tretjo pa so prišli že štirje. ${ }^{19}$ Naj pove, kdor more, koliko ljudi je bilo nanovačenih v vseh 30 utrdbah.

\section{Rešitev:}

Po prvem postanku sta bila torej 2, po drugem so bili 4, po tretjem jih je bilo 8 , po četrtem 16 , po petem 32 , po šestem 64 , po sedmem 128 , po osmem 256 , po devetem 512, po desetem 1024, po enajstem 2048, po dvanajstem 4096, po trinajstem 8192 , po štirinajstem 16384, po petnajstem 32768 , po šestnajstem 65536, po sedemnajstem 131072, po osemnajstem 262144, po devetnajstem 524288, po dvajsetem 1048576, po enaindvajsetem 2097152, po dvaindvajsetem 4194304, po triindvajsetem 8388608, po štiriindvajsetem 16777216, po petindvajsetem 33554432, po šestindvajsetem 67108864, po sedemindvajsetem 134217728, po osemindvajsetem 268435456, po devetindvajsetem 536870912, po tridesetem $1073741824 .^{20}$

18 Naloga ima poleg podane še druge možne rešitve. Če podano rešitev prikažemo v obliki (o, 5, 5), kjer vsako število v trojki predstavlja število polnih stekleničk, dodeljenih posameznemu sinu, lahko druge možne rešitve prikažemo na sledeč način: $(5,4,1),(5,3,2),(4,4,2),(4,3,3)$.

$19 \mathrm{~V}$ izvirniku je na tem mestu očitna napaka, ki je v prevodu odpravljena. Dobesedni prevod izvirnika se glasi: »/.../v tretjo pa so prišli že trije.»

20 Rešitev zahteva izračun potenc števila 2 vse do tridesete $\left(2^{30}=1073741824\right)$. Takšen izračun temelji na postopku, imenovanem duplatio (podvajanje), ki je služil kot ena temeljnih operacij znotraj aritmetike. Alkvinovim sodobnikom so tovrstne naloge povzročale neprimerljivo več preglavic kot nam, in sicer predvsem zaradi neobstoja žepnega računala ter nepriročnega sistema zapisovanja števil, ki ni omogočal podpisovanja, kar je pri računanju $z$ velikimi števili še posebej neugodno. O težavnosti računanja z velikimi števili priča tudi dejstvo, da se v mnogih rokopisih Nalog na tem mestu pojavljajo napačne vrednosti potenc števila 2, še zlasti tistih z eksponentom večjim od 15. Najverjetneje so si srednjeveški učenci pri računanju s tako velikimi števili pomagali $z$ abakom. Medtem ko Alkvin predlaga rešitev na dolg način - s pomočjo delnih vsot - bi se moderni reševalec te naloge gotovo raje lotili po preprostejšem in manj zamudnem postopku: $\mathrm{z}$ nastavitvijo geometrijske vrste $1+1+2+4+\ldots+2^{29}=2^{30}$ in seveda s pomočjo žepnega računala. 


\section{NALOGA O VOLU}

Koliko stopinj pusti vol, ki orje cel dan, v zadnji brazdi?

Rešitev:

Vol v zadnji brazdi ne pusti nobene stopinje, saj sam hodi pred oralom, ta pa mu sledi. Kajti kolikor stopinj vol kot prvi vtisne v neobdelano zemljo, toliko jih oralo, ki mu sledi, razorje in izbriše. Zato v zadnji brazdi ni moč opaziti nobene volove stopinje.

\section{NALOGA O ČLOVEKU}

Povej mi, prosim, koliko ornih brazd bo človek vrezal v svoje polje, če bo na vsakem od dveh koncev polja napravil 3 obrate.

Rešitev:

$\mathrm{Na}$ enem koncu polja 3 obrate, na drugem prav tako 3 obrate, kar znese 7 ornih brazd. ${ }^{21}$

\section{NALOGA O DVEH KMETIH, KI STA GNALA VOLE}

Dva kmeta sta po cesti gnala vole. Prvi je rekel drugemu: »Daj mi 2 vola in imel jih bom toliko, kolikor jih imaš ti.« Drugi pa pravi: »Daj mi še ti 2 vola in imel jih bom dvakrat toliko kot ti.« Naj pove, kdor želi, koliko volov je bilo skupaj in koliko jih je imel vsak od njiju na začetku.

\section{Rešitev:}

Na začetku je tisti, ki je prosil, naj mu drugi da 2 vola, imel 4 vole. Drugi pa je imel 8 volov. Ker ga je prvi prosil, mu je drugi seveda dal dva vola. Tako je imel vsak po 6 volov. Nato pa je tisti, ki je bil prvi dobil, drugemu, ki jih je imel 6, 2 vrnil, da jih je imel 8 , kar je $2 \times 4$, njemu samemu pa so ostali 4 , kar je polovica od $8 .{ }^{22}$

\section{NALOGA O TREH BRATIH, KI SO IMELI VSAK PO ENO SESTRO}

Bili so trije bratje, ${ }^{23}$ ki so imeli vsak po eno sestro, in morali so prečkati reko. Vsak od njih pa je čutil silno poželenje do sestre enega svojih dveh tovarišev. Ko so prišli do reke, so našli samo majhen čolnič, v katerem pa sta lahko reko naenkrat prečkala samo dva izmed njih. Naj pove, kdor more, na kakšen način so prečkali reko, da ni bila nobena od sester oskrunjena s strani moških.

Rešitev:

Najprej bi se v čoln vkrcala jaz in moja sestra ter prečkala reko. ${ }^{24}$ Nato bi svojo sestro izkrcal iz čolna in se zapeljal nazaj do brega. Nato bi se vkrcali sestri drugih dveh mož, namreč tistih, ki sta ostala na obrežju. Ko bi oni dve ženski izstopili

21 Iz izvirnika ni povsem jasno, ali se v rešitvi štejejo brazde ali obrati na vsakem koncu polja. Najverjetneje je mišljeno, da je človek napravil skupaj 6 obratov in 7 ornih brazd.

22 Nalogo lahko rešimo s sistemom dveh linearnih enačb z dvema neznankama. Zaradi nejasnosti besedila bi se reševalec problema lotil tako, da bi nastavil naslednji sistem: $x+2=y-2$ in $y+2=2(x-2)$, pri čemer $\mathrm{x}$ in y predstavljata začetno število volov posameznega udeleženca. Po razrešitvi sistema dobimo rešitev $x=10, y=14$. Toda $\mathrm{v}$ Alkvinovi rešitvi se upošteva, da je do druge menjave prišlo šele po tem, ko je bila opravljena prva menjava (ta podatek je podan šele v rešitvi!), kar se prevede v naslednji sistem: $x+2=y-2$ in $y=2 x$. Po razrešitvi sistema dobimo rešitev $x=4, y=8$.

23 bratje (lat. fratres) - angleški prevajalec Peter J. Burkholder tukaj sugerira prevod "moški» namesto »bratje«, kar utemelji s trditvijo, da je avtor najbrž mislil, da so ti moški bratje samo v odnosu do svojih sester, nikakor pa ne med seboj.

24 Sprememba osebe in naklona je vizvirniku. 
iz čolna, bi vanj vstopila moja sestra, ki je prva prečkala reko, in pripeljala čoln $\mathrm{k}$ meni. Ko bi ona stopila ven, bi se v čoln vkrcala oba brata in prečkala reko. Tedaj bi se eden izmed njiju skupaj s svojo sestro vkrcal v čoln in odplul k nama. Jaz in ta, ki je krmaril, bi šla čez, moja sestra pa bi ostala na bregu. ${ }^{25}$ Ko bi se prepeljala na drugi breg, bi še tretja sestra odpeljala čoln čez, vzela mojo sestro s seboj in se vrnila k nam. Tisti pa, čigar sestra je ostala na drugem bregu, bi stopil v čoln in jo prepeljal s seboj. Tako bi se prevoz iztekel, ne da bi prišlo do nečistega stika.

\section{NALOGA O VOLKU, KOZI IN ZELJNI GLAVI}

Neki človek je moral čez reko spraviti volka, kozo in zeljno glavo. Uspelo pa mu je najti le takšen čoln, ki je lahko hkrati peljal samo dve od teh reči. Ukazano pa mu je bilo, naj prevoz opravi tako, da bodo volk, koza in zeljna glava ostali celi. Naj pove, kdor more, kako mu je uspelo vse tri prepeljati čez reko nepoškodovane.

Rešitev:

Po podobnem postopku kot zgoraj bi najprej prepeljal kozo ter pustil volka in zelje na bregu. Nato bi se vrnil, prepeljal volka, ga izkrcal in v čoln vzel kozo ter jo prepeljal čez. Kozo bi izkrcal in čez prepeljal zeljno glavo. Nato bi se znova vrnil po kozo, jo vkrcal in prepeljal čez. Če bom tako ravnal, se bo prevoz iztekel uspešno in brez nevarnosti krvavega obračuna. ${ }^{26}$

\section{NALOGA O MOŠKEMINŽENSKIMASE ENEGA OTOVORJENEGA VOZA $^{27}$}

Moški in ženska, vsak mase enega otovorjenega voza, ki sta imela dva otroka, skupaj mase enega otovorjenega voza, sta morala prečkati reko. Našla sta čoln, ki pa ni mogel prevažati tovora, težjega od enega otovorjenega voza. Naj opravi prevoz, kdor meni, da zmore, tako da čoln ne potone.

Rešitev:

$\mathrm{Na}$ enak način kot zgoraj bi se najprej vkrcala otroka in prečkala reko, eden izmed njiju pa bi čoln pripeljal nazaj. Nato bi se v čoln vkrcala mati in šla čez. Tedaj bi sin čoln prepeljal nazaj, njegov brat pa bi se vkrcal. Nato bi oba prečkala reko, eden izmed njiju pa bi čoln odpeljal do očeta. Nato bi reko prečkal oče, sin pa bi ostal na bregu. In znova bi se sin, ki je šel prej čez reko, vkrcal v čoln in ga odpeljal do brata. Tedaj naj se vkrcata oba in prečkata reko. S takšno veslaško prebrisanostjo bo morda prevoz opravljen, ne da bi čoln potonil.

\section{NALOGA O JEŽIH}

Dva ježa, samec in samica, ki sta imela dva mladiča, tehtala pa sta en funt, sta želela prečkati reko. ${ }^{28}$

25 Nam. skupaj s sestro tistega, ki je z njo pravkar prišel nazaj.

26 Drugi način: 1) voznik na drugi breg prepelje kozo in se vrne sam; 2) voznik na drugi breg prepelje zeljno glavo, tam vkrca kozo in jo prepelje nazaj; 3) voznik na drugi breg prepelje volka in se vrne sam; 4) naposled voznik vkrca še kozo in jo prepelje na drugi breg.

27 mase enega otovorjenega voza - vizvirniku je besedna zveza plaustri onusti "otovorjenega voza", ki se je lahko v primernem kontekstu rabila tudi kot enota za maso tovora, ki ga prenese en voz.

28 Izjava je očitno nepopolna: iz dejstva, da je postopek rešitve enak tistemu v predhodni nalogi, lahko sklepamo, da je masa posameznega roditelja enaka skupni masi obeh mladičev (en funt) in da lahko čoln hkrati prevaža samo tovor, katerega masa ne presega enega funta. 
Rešitev:

Podobno kot zgoraj bi reko najprej prečkala mladiča, eden od njiju pa bi čoln pripeljal nazaj. Vanj bi se vkrcal oče in se prepeljal čez. Tisti mladič, ki je šel prej čez z bratom, bi čoln odpeljal do brega, vanj pa bi se zopet vkrcal njegov brat in oba prepeljal čez. Eden izmed njiju bi se izkrcal na breg, drugi pa bi čoln odpeljal do matere. Ta bi se vkrcala in se prepeljala čez. Ko bi izstopila, bi se njen sin, ki je šel prej čez z bratom, znova vkrcal v čoln in ga prepeljal nazaj na breg k bratu. Nato bi se oba vkrcala in se prepeljala čez. In tako bi bil prevoz opravljen brez strahu, da bi prišlo do brodoloma.

\section{NALOGA O POLJU IN OVCAH, KI JIH JE TREBA NANJ NAMESTITI}

Imamo polje, ki v dolžino meri 200 čevljev, v širino pa 100 čevljev. Tja želim namestiti ovce, in sicer tako, da bo vsaka ovca imela v dolžino 5 čevljev in $\mathrm{v}$ širino 4 čevlje prostora. Naj, prosim, pove, kdor je sposoben, za koliko ovac je prostora na tem polju.

Rešitev:

Celotno polje je dolgo 200 čevljev in široko 100 čevljev. 200 deli s 5, da dobiš 40. Nato 100 deli s 4 . Ena četrtina od 100 je 25 . Zmnoži torej $40 \times 25$ ali $25 \times 40$, da dobiš število 1000 . Za prav toliko ovac je torej tam prostora.

\section{NALOGA O NERAVNEM POLJU}

Imamo neravno polje, katerega bočni stranici merita vsaka po 100 pertik, prva čelna stranica meri 50 pertik, v sredini je polje široko 60 pertik, druga čelna stranica pa zopet 50 pertik. Naj pove, kdor more, koliko aripenov mora to polje oklepati.

Rešitev:

Dolžina tega polja je 100 pertik, dolžina obeh čelnih stranic je 50, srednja dolžina pa 60 pertik. Seštej dolžino obeh čelnih robov in srednjo dolžino, da dobiš 160 . Od tega vzemi tretjino, to je 53, in jo pomnoži s 100, da dobiš 5300 . Rezultat razdeli na 12 enakih delov, da dobiš 441 . To pa znova razdeli na 12 delov, da dobiš 37 . Toliko aripenov meri to polje. ${ }^{29}$

29 Alkvin ploščino tega neravnega polja izračuna s približno formulo, saj predpostavi, da je ena bočna stranica enaka dolžini polja, drugo pa na sredini prelamlja srednja dolžina (6o pertik). Alkvin predlaga takšen izračun: $\frac{50+60+50}{3} \times 100=\frac{160}{3} \times 100$. Avtor rezultat računa $160: 3=53,33 \ldots$ zaokroži na celo število in dalje računa s 53 . Polje torej meri 5300 pertik ${ }^{2}$, kar je po pretvorbi ( 1 aripen $=144$ pertik ${ }^{2}$ ) 37 aripenov. Gl. skico.

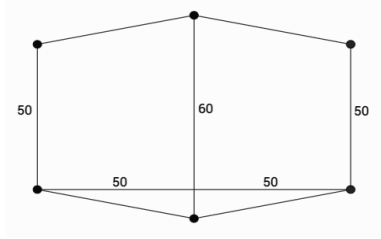




\section{NALOGA O ŠTIRIKOTNEM POLJU}

Imamo štirikotno polje, katerega prva bočna stranica meri 30 pertik, druga bočna stranica 32 pertik, prva čelna stranica 34, druga čelna stranica pa 32. Naj pove, kdor more, koliko aripenov mora biti zaobjetih $\mathrm{v}$ tem polju.

Rešitev:

Bočni stranici tega polja zneseta skupaj 62 pertik. Razpolovi 62, da dobiš 31. Čelni stranici tega polja zneseta skupaj 66 pertik. Razpolovi 66, da dobiš 33. Zmnoži $31 \times 33$, da dobiš 1023. Kakor zgoraj, dobljeno dvakrat deli z 12, to je $1023: 12$, da dobiš 85 , nato pa še $85: 12$, da dobiš 7 . V tem polju je torej 7 aripenov. ${ }^{30}$

\section{NALOGA O TRIKOTNEM POLJU}

Imamo trikotno polje, katerega bočni stranici merita 30 pertik, čelna stranica pa 18 pertik. Naj pove, kdor more, koliko aripenov mora oklepati.

Rešitev:

Seštej obe dolžini tega polja, da dobiš 60 . Razpolovi 60 , da dobiš 30 . Ker pa čelna stranica meri 18 pertik, razpolovi 18 , da dobiš 9 . Zmnoži $9 \times 30$, da dobiš 270 . Nato dobljeno dvakrat deli z 12 , to je $270: 12$, da dobiš $22 \frac{1}{2}$ potem pa znova $22 \frac{1}{2}: 12$, da dobiš en aripen in $10 \frac{1}{2}$ pertik. $^{31}$

\section{NALOGA O POLJU V OBLIKI KROGA}

Imamo polje $\mathrm{v}$ obliki kroga, ki v obseg meri 400 pertik. Povej, koliko aripenov mora zaobjeti.

\section{Rešitev:}

Četrtina tega polja, ki zaobjema 400 pertik, meri 100 pertik. Če to število

30 Tudi v tem primeru se Alkvin za izračun ploščine polja posluži približne formule, $\mathrm{v}$ široki rabi vse od časa starega Egipta, s katero se nepravilni štirikotnik $a, b, c, d$ poenostavi do pravokotnika z dimenzijami, enakimi aritmetični sredini dolžin nasproti ležečih si stranic: $\frac{a+c}{2}$ in $\frac{b+d}{2}$. Čim bliže so si med seboj dolžine nasproti ležečih si stranic, tem natančnejši je rezultat. Ploščina našega polja se torej po tej približni formuli izračuna takole: $\frac{30+32}{2} \times \frac{32+34}{2}=31 \times 33=1023$ pertik ${ }^{2}$. Nadalje $\frac{\frac{1023}{12}}{12}=7$ aripenov. Tudi v tem primeru so rezultati zaokroženi na cela števila: $\frac{1023}{12}=85,25 \doteq 85$ in dalje $\frac{85}{12}=7,08 \doteq 7$. Gl. skico.

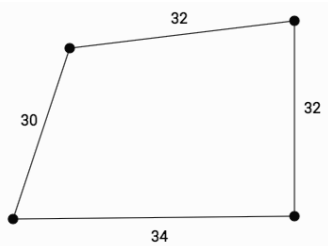

31 Za izračun ploščine trikotnika Alkvin ne uporabi standardne formule $\frac{c \times V c}{2}$, ampak zelo nenatančno formulo $\frac{c}{2} \times \frac{a+a}{2}$, pri čemer je drugi faktor aritmetična sredina krakov: $\frac{30+30}{2}=30$. To pomeni $9 \times 30=270$ pertik $^{2}$. Pravilna vrednost, izračunana po formuli $\frac{c \times V c}{2}$, je 257,56 pertik $^{2}$. Alkvin nato po istem postopku kot v nalogi 23 (dvakratko deljenje z 12) rezultat iz kvadratnih pertik pretvori v aripene, vendar napravi v postopku napako. Pravilen rezultat bi bil 1 aripen in 126 pertik $^{2}$. 
pomnožiš s samim seboj, to je s 100, dobiš 10000. To moraš razdeliti na 12 delov. Ena dvanajstina od 10000 je 833 . Ko to število ponovno deliš z 12, dobiš 69. Toliko aripenov torej zaobjema polje. ${ }^{32}$

\section{NALOGA O POLJU, PASJEM TEKU IN ZAJČJEM BEGU}

Imamo 150 čevljev dolgo polje. Na enem koncu je stal pes, na drugem zajec. Zajec se požene v dir, pes pa za njim. Toda $\mathrm{v}$ času, ko je pes $\mathrm{v}$ enem skoku premagal razdaljo 9 čevljev, je zajec opravil pot 7 čevljev. Naj pove, kdor želi, koliko čevljev in koliko skokov je opravil pes na lovu in koliko zajec na begu, dokler slednji ni bil ujet.

\section{Rešitev:}

Dolžina tega polja je 150 čevljev. Vzemi polovico od 150, da dobiš 75 . Pes je v enem skoku premagal razdaljo 9 čevljev. 75 pomnoženo z 9 znese 675 - toliko čevljev je pretekel pes v lovu na zajca, dokler ga ni zgrabil s svojimi čvrstimi čekani. Toda, ker je zajec v enem skoku premagal razdaljo 7 čevljev, pomnoži $75 \times 7$, da dobiš 525 . Toliko čevljev je zajec na begu pretekel, dokler ga ni pes ujel. ${ }^{33}$

\section{NALOGA O ŠTIRIKOTNEM MESTU}

Imamo štirikotno mesto, katerega prva bočna stranica meri 1100 čevljev, druga bočna stranica 1000 , čelni stranici pa vsaka 600. Vanj želim postaviti ostrešene hiše, ${ }^{34}$ in sicer tako, da bo vsaka hiša dolga 40 čevljev in široka 30 čevljev. Naj pove, kdor more, za koliko hiš mora biti v mestu prostora.

Rešitev:

Če združimo obe dolžini tega mesta, dobimo 2100. Če na enak način združimo obe širini, to znese 1200 . Vzemi torej polovico od 1200, da dobiš 600 , nato vzemi še polovico od 2100 , da dobiš 1050 . In ker meri vsaka hiša $\mathrm{v}$ dolžino 40 čevljev in v širino 30 čevljev, vzemi eno štiridesetino od 1050, da dobiš 26 . Nato vzemi še eno tridesetino od 600 , da dobiš $20.20 \times 26$ pa je 520 . Za toliko hiš mora biti v mestu prostora.

\section{NALOGA O TRIKOTNEM MESTU}

Imamo trikotno mesto, katerega bočni stranici merita vsaka po 100

32 Če je $o$ obseg in $S$ ploščina kroga, bomo ploščino izračunali po formuli $S=\frac{o^{2}}{4 \pi}$. Čeprav je bila takrat natančna vrednost števila $\pi$ že znana $\left(\pi=\frac{22}{7} \doteq 3,14\right)$, so bili pri praktični geometriji navadno $\mathrm{v}$ rabi približki: $\pi \doteq 3$ ali $\pi \doteq 4$. Alkvin račun nastavi takole: $S=\frac{o}{4} \times \frac{o}{4}=\frac{\sigma^{2}}{16}$, pri čemer privzame $\pi=4$. Če za izračun ploščine privzamemo natančno vrednost števila $\pi$, dobimo rezultat $S=88,38$ aripenov.

33 Polje, na katerem se odvija v nalogi opisani prizor, je dolgo najmanj 675 čevljev in ne samo 150 čevljev, kakor zavajajoče navaja Alkvin. 150 čevljev namreč znaša samo začetna razdalja med psom in zajcem. Ker se ob vsakem opravljenem skoku razdalja med psom in zajcem zmanjša za dva čevlja, izračunamo število skokov, ki jih mora opraviti pes, da ujame zajca, na sledeči način: $2 x=150$. Dobimo rezultat $x=75$. Da dobimo razdaljo, ki jo preteče pes, v čevljih, pomnožimo še število skokov z dolžino posameznega skoka: $75 \times 9=675$. Enako storimo v primeru zajca.

34 Dobesedni prevod izvirnika (lat. tecta domorum) bi se glasil »strehe hiš«, toda ker je v nadaljevanju govora o hišah (lat. casae), prevajam tukaj »ostrešene hiše«. 
čevljev, čelna stranica pa 90 čevljev. V tem mestu želim zgraditi hiše, in sicer tako, da bo posamezna hiša v dolžino merila 20 čevljev, v širino pa 10 čevljev. Naj pove, kdor more, za koliko hiš mora biti prostora.

Rešitev:

Če torej združimo obe enaki stranici tega mesta, dobimo 200. Vzemi polovico od 200, da dobiš 100 . Toda ker čelni rob meri 90 čevljev, vzemi še polovico od 90, da dobiš 45. In ker vsaka hiša v dolžino meri 20 čevljev, v širino pa 10 čevljev, gre $20 \mathrm{v} 100$ petkrat in 10 v 40 štirikrat. Zmnoži torej $5 \times 4$, da dobiš 20. Za toliko takšnih hiš bo prostora v mestu. ${ }^{35}$

\section{NALOGA O OKROGLEM MESTU}

Imamo okroglo mesto, ki v obseg meri 8000 čevljev. Naj pove, kdor more, koliko hiš mora zaobjeti, da bo vsaka hiša v dolžino merila 30 čevljev, v širino pa 20 čevljev.

Rešitev:

Obseg tega mesta meri 8000 čevljev. Če ga razdelimo v razmerju 3:2, , $^{36}$ dobimo 4800 in 3200 . V prvem številu je zajeta dolžina hiš, $v$ drugem širina. Od obeh vsot vzemi polovico, da od večje ostane 2400, od manjše pa 1600 . 1600 razdeli na 20 delov in dobil boš osemdesetkrat 20 . Na enak način razdeli večjo vsoto, to je 2400 , na 30 delov, da dobiš osemdesetkrat 30 . Zmnoži $80 \times 80$, da dobiš 6400. Toliko hiš je moč zgraditi v takšnem mestu po zgoraj napisani nalogi. ${ }^{37}$

\section{NALOGA O BAZILIKI}

Imamo baziliko, ki v dolžino meri 240 čevljev, v širino pa 120 čevljev. Vsak posamezen tlakovec bazilikinega tlaka meri v dolžino 23 palcev, to je en čevelj in 11 palcev, v širino pa 12 palcev, to je en čevelj. Naj pove, kdor želi, koliko tlakovcev bo potrebnih za tlakovanje celotne bazilike.

\section{Rešitev:}

126 tlakovcev zapolni 240 čevljev dolžine, 120 tlakovcev pa 120 čevljev širine, saj vsak tlakovec $v$ širino meri en čevelj. Zmnoži torej $120 \times 126$, da dobiš 15120 . Toliko tlakovcev lahko torej pokrije pod takšne bazilike. ${ }^{38}$

35 Alkvin meni, da lahko trikotno mesto preoblikuje v pravokotnik z dimenzijami $a=100$ in $b=45$, kar je z vidika ploščine popolnoma upravičeno. Nato pa računa, za koliko hiš bo prostora v pravokotniku z dimenzijami $a=100$ in $b=40$ (!); prehod na manjši pravokotnik je seveda popolnoma neupravičen in botruje napačnemu končnemu rezultatu. Razlog za ta prehod je bodisi dejstvo, da 45 ni deljivo z 10, bodisi upoštevanje, da gre kljub preoblikovanju v pravokotnik še vedno za trikotno mesto, $\mathrm{v}$ katerega ne moremo postaviti enakega števila pravokotnih hiš kot $\mathrm{v}$ pravokotno mesto $\mathrm{z}$ enako ploščino. Alkvinov rezultat 20 je v vsakem primeru previsok.

36 v razmerju 3:2 - lat. sesqualtera proportione dob. 'v poldrugem razmerju'. Gre za razmerje, pri katerem večje število (3) vsebuje celotno manjše število (2) in še njegovo polovico (1).

37 Alkvin razdeli obseg kroga v razmerju 3:2, saj so v enakem razmerju tudi stranice hiš, ki jih je treba postaviti v mesto. Nato krog preoblikuje v pravokotnik z dimenzijami $a=2400$ in $b=1600$ in vanj po običajnem postopku, uporabljenem že v nalogi 9 , razvrsti $\frac{2400}{30} \times \frac{1600}{20}=80 \times 80=6400$ hišs.

38 Bazilika je široka 120 čevljev in dolga $240 \times 12=2880$ palcev. Ker je vsak tlakovec širok 1 čevelj in dolg 23 palcev, vsebuje 120 čevljev širine 120 tlakovcev, 2880 palcev dolžine pa $2880: 23=125,21$ 


\section{NALOGA O KLETI}

Imamo klet, ki v dolžino meri 100 čevljev, v širino pa 64 čevljev. Naj pove, kdor more, koliko sodov lahko hrani, če en sod meri 7 čevljev v dolžino in 4 čevlje v širino po sredini, in če ima klet en prehod, ki je širok 4 čevlje.

\section{Rešitev:}

7 gre v 100 štirinajstkrat, 4 pa v 64 šestnajstkrat. Od tega se na račun prehoda, ki vodi po celotni dolžini te kleti, odvzame 4 čevlje. Ker gre torej $4 \mathrm{v}$ 60 petnajstkrat, 7 v 100 pa štirinajstkrat, zmnoži $15 \times 14$, da dobiš 210 . Toliko sodov z zgoraj predpisanimi dimenzijami lahko hrani takšna klet. ${ }^{39}$

\section{NALOGA O NEKEM HIŠNEM GOSPODARJU, KI JE RAZDELIL ŽITO}

Neki hišni gospodar je imel 20 služabnikov. Ukazal je, naj se mednje razdeli 20 mernikov žita na sledeči način: moški naj prejmejo vsak po 3 mernike, ženske vsaka po 2 mernika, otroci pa vsak po eno polovico mernika. Naj pove, kdor more, koliko moških, koliko žensk in koliko otrok mora biti med služinčadjo.

\section{Rešitev:}

Zmnoži $1 \times 3$, da dobiš 3 , to pomeni, da je en moški prejel 3 mernike. Tako zmnoži tudi $5 \times 2$, da dobiš 10 , to pomeni, da je 5 žensk prejelo 10 mernikov. Zmnoži pa še $7 \times 2$, da dobiš 14 , to pomeni, da je 14 otrok prejelo 7 mernikov. Seštej torej $1+5+14$, da dobiš 20 : to je vseh 20 služabnikov. Nadalje seštej še $3+7+10$, da dobiš 20 : to je 20 mernikov. Imamo torej hkrati 20 služabnikov in 20 mernikov. $^{40}$

\section{DRUGA TAKŠNA NALOGA}

Neki hišni gospodar je imel 30 služabnikov, med katere je ukazal razdeliti 30 mernikov žita. Ukazal pa je takole: moški naj prejmejo vsak po 3 mernike, ženske vsaka po 2 mernika, otroci pa vsak po eno polovico mernika. Naj razreši, kdor more, koliko moških, koliko žensk in koliko otrok je bilo med služinčadjo.

\section{Rešitev:}

Če zmnožiš $3 \times 3$, dobiš 9 . In če zmnožiš $5 \times 2$, dobiš 10 . Nadalje vzemi polovico od 22, da dobiš 11 . To pomeni, da so 3 moški prejeli 9 mernikov,

tlakovcev, kar avtor zaokroži na 126. Tako je za tlakovanje bazilike potrebnih $120 \times 126=15120$ tlakovcev.

39 Problem te naloge je, da rešitev nima praktične vrednosti, saj so dosegljivi le tisti sodi, ki ležijo neposredno ob prehodu.

40 Problemi razdelitve živeža, med katere uvrščamo ta in naslednje tri probleme, imajo pogosto več možnih rešitev, vendar avtor vselej poda samo eno. Nalogo rešimo z uporabo sistema dveh linearnih enačb s tremi neznankami, od katerih se je treba ene znebiti: $x+y+z=20$ in $3 x+2 y+\frac{z}{2}=20$, to je $6 x+4 y+z=40$, pri čemer je $\mathrm{x}$ število moških, $\mathrm{y}$ število žensk in $\mathrm{z}$ število otrok med služinčadjo. Sistem najlaže rešimo takole: (1) Iz druge enačbe izrazimo spremenljivko z: $z=40-6 x-4 y$. (2) Enačbi odštejemo in dobimo $5 x=20-3 y$. (3) S serijo poskusov najdemo par števil $\mathrm{x}$ in $\mathrm{y}$, ki zadosti enačbi $5 x=20-3 y$ in pri čemer je tudi z pozitivno celo število. Najlaže je, da po vrsti vstavljamo ničlo in sledeče pozitivne cele vrednosti spremenljivke y: $y=0, y=1, y=2, y=3$ itd. Enačba se izide pri vrednostih $y=0$ in $y=5$, in tako dobimo dve rešitvi: $x=1, y=5, z=14$ in $x=4, y=0, z=16$. Alkvin poda samo prvo rešitev: 1 moški, 5 žensk in 14 otrok. 
5 žensk 10 mernikov, 22 otrok pa 11 mernikov. Če seštejemo $3+5+22$, dobimo 30 služabnikov. Če pa seštejemo še $9+11+10$, dobimo 30 mernikov. Imamo torej hkrati 30 služabnikov in 30 mernikov. ${ }^{41}$

\section{3a. TRETJA TAKŠNA NALOGA}

Neki hišni gospodar je imel 90 služabnikov. Ukazal je, naj se jim razdeli 90 mernikov žita. Ukazal pa je tudi, naj moški prejmejo vsak po 3 mernike, ženske vsaka po 2 mernika, otroci pa vsak po eno polovico mernika. Naj pove, kdor meni, da zna, koliko moških, koliko žensk in koliko otrok je bilo med služinčadjo.

\section{Rešitev:}

Zmnoži $6 \times 3$, da dobiš 18 . Nato zmnoži $20 \times 2$, da dobiš 40 . Vzemi pa še polovico od 64, da dobiš 32 . To pomeni, da so 3 moški prejeli 18 mernikov, 20 žensk 40 mernikov, 64 otrok pa 32 mernikov. Če to seštejemo skupaj, namreč $6+20+64$, znese 90 služabnikov. Seštej še $18+40+32$, da dobiš 90 mernikov. Če primerjaš oba rezultata, imaš tako 90 služabnikov kot 90 mernikov. ${ }^{42}$

\section{4. ČETRTA TAKŠNA NALOGA}

Neki hišni gospodar je imel 100 služabnikov, med katere je ukazal razdeliti 100 mernikov žita, in sicer na način, da so moški prejeli vsak po 3 mernike, ženske vsaka po 2 mernika, otroci pa vsak po eno polovico mernika. Naj torej pove, kdor zmore, koliko moških, koliko žensk in koliko otrok je bilo med služinčadjo.

\section{Rešitev:}

$11 \times 3$ je 33 in $15 \times 2$ je 30 . Vzemi pa še polovico od 74 , da dobiš 37 . To pomeni, da je 11 moških prejelo 33 mernikov, 15 žensk 30 mernikov, 74 otrok pa 37 mernikov. Če to seštejemo skupaj, namreč $11+15+74$, znese 100 služabnikov. Enako seštej 33+30+37, da dobiš 100 mernikov. Če primerjaš oba rezultata, imaš tako 100 služabnikov kot 100 mernikov. ${ }^{43}$

\section{NALOGA O SMRTI NEKEGA HIŠNEGA GOSPODARJA}

Neki hišni gospodar je po smrti za seboj pustil otroke, 960 zlatnikov dediščine in nosečo ženo. Določil je: če se rodi sin, naj prejme tri četrtine premoženja, to je 9 unč, ${ }^{44}$ njegova mati pa eno četrtino premoženja, to je 3 unče. Če pa se rodi hči, naj prejme sedem dvanajstin premoženja, to je 7 unč,

$41 \mathrm{Za}$ postopek gl. opombo $\mathrm{k}$ rešitvi naloge 32. Naloga ima tri rešitve: $x=6, y=0, z=24$ in $x=3, y=5, z=22$ in $x=0, y=10, z=20$. Alkvin poda samo drugo.

42 Za postopek gl. opombo k rešitvi naloge 32. Naloga ima sedem rešitev, Alkvin pa poda samo eno: $x=6, y=20, z=64$.

43 Za postopek gl. opombo k rešitvi naloge 32. Naloga ima sedem rešitev, Alkvin pa poda samo eno: $x=11, y=15, z=74$.

$\begin{aligned} & x=11, y=15, z=74 . \\ & 44\end{aligned}$ unč (lat. uncias IX) - gl. opombo k nalogi 7. Osnovni pomen unče je $\frac{1}{12}$ neke večje enote, tukaj
je je ta »večja enota« celotna dediščina, torej 960 zlatnikov. 9 unč je torej $\frac{9}{12}$ oz. $\frac{1}{4}$ od 960 . V nalogi
se pojavljajo tudi rimski izrazi za različne deleže funta:

quadrans $=\frac{3}{12}=\frac{1}{4}$ funta, quincunx $=\frac{5}{12}$ funta, septunx $=\frac{7}{12}$ funta, bes $($ bis $)=\frac{8}{12}=\frac{2}{3}$ funta, dodrans $=\frac{9}{12}=\frac{3}{4}$ funta .

Zato tudi v slovenskem prevodu ohranjam besedni zapis deležev. 
njena mati pa pet dvanajstin, to je 5 unč. Pripetilo pa se je, da je rodila dvojčka, in sicer dečka in deklico. Naj razvozla, kdor more, koliko je prejela mati, koliko sin in koliko hči.

\section{Rešitev:}

Seštej torej $9+3$, da dobiš 12 . V enem funtu je namreč 12 unč. Nato na enak način seštej $7+5$, da dobiš spet $12.2 \times 12$ znese 24 unč. 24 unč je enako 2 funta, to pa je 40 zlatnikov. 960 torej deli s 24 . Ena štiriindvajsetina tega števila je 40. Ker je sinov delež tri četrtine, mu daj 9 deležev po 40 zlatnikov. Tako sin dobi $9 \times 40$ zlatnikov, to je 18 funtov, kar je enako 360 zlatnikov. In ker je mati v razmerju do sina prejela tri dvanajstine, v razmerju do hčere pa pet dvanajstin, seštejemo $3+5$, da dobimo 8 . Ker to pomeni, da dobi osem dvanajstin, vzemi 8 delov po $40.8 \times 40$ zlatnikov je torej prejela mati, to je 16 funtov, kar je enako 320 zlatnikov. Nato, ker je rečeno, da dobi sedem dvanajstin, vzemi 7 delov po 40. Potem zmnoži $7 \times 40$, da dobiš 14 funtov, kar je enako 280 zlatnikov. To je prejela hči. Seštej torej $360+320+280$ in dobiš 960 zlatnikov oziroma 48 funtov. ${ }^{45}$

\section{NALOGA O STARČEVEM POZDRAVU DEČKU}

Neki starec je pozdravil dečka in mu rekel: »Žível, sine, žível, še enkrat toliko, kolikor si že preživel, in še enkrat toliko in še trikrat toliko; Bog pa naj ti nameni še eno od mojih let, tako da jih boš dopolnil 100.« Naj dožene, kdor more, koliko je bil deček takrat star.

\section{Rešitev:}

Takrat, ko je starec rekel: „Žível, še enkrat toliko, kolikor si že preživel,« je bil deček star 8 let in 3 mesece. Dvakrat toliko je 16 let in 6 mesecev, še dvakrat toliko je 33 let. Če to zmnožimo s 3, dobimo 99 let. Če dodamo še eno, dobimo 100 let. $^{46}$

\section{NALOGA O NEKEM ČLOVEKU, KI JE ŽELEL ZGRADITI HIŠO}

Neki človek, ki je želel zgraditi hišo, je zaposlil 6 zidarjev, od katerih je bilo 5 mojstrov in en vajenec. Tisti, ki je želel graditi, in zidarji so med seboj sklenili dogovor, da bo njihova skupna dnevna mezda znašala 25 denarijev, in sicer tako, da bo vajenec dobil pol toliko kot vsak mojster. Naj pove, kdor more, koliko bo vsak od njih dobil na dan.

\section{Rešitev:}

45 Alkvin problem reši tako, da razdeli celotno dediščino na polovico, nato pa vsak del posebej razdeli na način, določen v oporoki. Od prve polovice, to je od 480 zlatnikov, jih da $\frac{9}{12}$, to je 320 , sinu in $\frac{3}{12}$, to je 120 , materi. Od druge polovice pa da $\frac{7}{12}$, to je 280 , hčeri in $\frac{5}{12}$, to je 200 , materi. Mati torej skupaj dobi 320, sin 360, hči pa 280 zlatnikov, kar skupaj znese 960 zlatnikov, to pa je vrednost celotne dediščine. Vendar s takšno razdelitvijo razmerje med vsoto, ki jo prejme mati, in tisto, ki jo prejmeta otroka, ne ustreza navodilu v nalogi. Natančen rezultat dobimo na sledeč način: če mati dobi $x$, dobi sin $3 x$ in hči $\frac{7}{5} x$. Nastavimo torej enačbo $x+3 x+\frac{7}{5} x=960$, jo rešimo in dobimo $x=177,77$. Sin bi torej moral dobiti 533,31 zlatnikov, hči pa 248,85 zlatnikov.

46 Gre za linearni problem $z$ eno neznanko, ki ga rešimo $z$ enačbo $x+x+2 x+8 x+1=100$, pri čemer je $\mathrm{x}$ dečkova starost $\mathrm{v}$ trenutku starčevega pozdrava. Enačbo rešimo in dobimo pravilno rešitev $x=8 \frac{1}{4}$, kar v koledarskem sistemu pomeni 8 let in 3 mesece. 
Najprej vzemi 22 denarijev in jih razdeli na 6 delov. Tako daj vsakemu mojstru, ki jih je 5 , po 4 denarije. $5 \times 4$ je namreč 20 . Nato vzemi preostala 2 denarija, kar je polovica od 4 , in ju daj vajencu. Tako ostanejo 3 denariji, ki jih razdeli takole: razdeli vsak denarij na 11 delov. $3 \times 11$ znese 33 . Vzemi 30 delov in jih razdeli med 5 mojstrov. $5 \times 6$ znese 30 . Vzemi preostale 3 dele, kar je polovica od 6 , in jih daj vajencu. ${ }^{47}$

\section{NALOGA O NEKEM ČLOVEKU, KI JE KUPIL STO ŽIVALI}

Neki človek je želel kupiti 100 živali različnih vrst za 100 zlatnikov, in sicer tako, da bi kupil konja za 3 zlatnike, vola za 1 zlatnik in 24 ovac za 1 zlatnik. Naj pove, kdor zmore, koliko konjev, koliko volov in koliko ovac je kupil.

Rešitev:

Zmnoži 3×23, da dobiš 69 . Nato $2 \times 24$, da dobiš 48 . Dobimo torej $23 \mathrm{konjev}$ za 69 zlatnikov, 48 ovac za 2 zlatnika in 29 volov za 29 zlatnikov. Seštej torej $23+48+29$, da dobiš 100 živali. Nato seštej 69+2+29, da dobiš 100 zlatnikov. Vse skupaj je torej 100 živali in 100 zlatnikov. $^{48}$

\section{NALOGA O NEKEM KUPCU NA VZHODU}

Neki človek je želel s 100 zlatniki na Vzhodu kupiti 100 živali različnih vrst. Svojemu slugi je ukazal, naj da za kamelo 5 zlatnikov, za osla zlatnik in za 20 ovac zlatnik. Naj pove, kdor želi, koliko kamel, oslov in ovac je bilo v kupčiji za 100 zlatnikov.

Rešitev:

Če pomnožiš $19 \times 5$, dobiš 95 , to pomeni, da je 19 kamel kupil za 95 zlatnikov. Tem dodaj zlatnik za enega osla, da znese skupaj 96 zlatnikov. Nato zmnoži $4 \times 20$, da dobiš 80 , to pomeni, da je za 4 zlatnike kupil 80 ovac. Seštej torej $19+1+80$, da dobiš 100 . To je 100 živali. Nato seštej $95+1+4$, da dobiš 100 zlatnikov. Vse skupaj je torej 100 živali in 100 zlatnikov. ${ }^{49}$

\section{NALOGA O ČLOVEKU IN OVCAH NA GORSKI PAŠI}

Neki človek je v planinah videl ovce na paši in dejal: »O, da bi jih imel toliko in še enkrat toliko in še polovico od polovice in še polovico od te polovice. Tako bi jaz skupaj z njimi kot stoti prišel na svoj dom.« Naj razreši, kdor more, koliko ovac je človek videl na paši.

47 Vsak mojster tako dobi $4+\frac{6}{11}$ denarija, vajenec pa $2+\frac{3}{11}$ denarija. Alkvin nalogo reši tako, da med zidarje najprej razdeli 22 denarijev na zahtevani način ( 4 vsakemu mojstru in 2 vajencu), nato pa vsak preostali denarij razdeli na 11 delov in dobi $\frac{33}{11}$, ki jih lahko na zahtevani način razdeli med zidarje ( $\frac{6}{11}$ vsakemu mojstru in $\frac{3}{11}$ vajencu). Moderni reševalec bi nalogo gotovo raje rešil $\mathrm{z}$ nastavitvijo linearne enačbe $5 x+\frac{1}{2} x=25$, pri čemer je $\mathrm{x}$ dnevna mezda posameznega mojstra. Enačbo rešimo in dobimo $x=\frac{50}{11}=4+\frac{6}{11}=4,55$. Na koncu izračunamo še $\frac{1}{2} x$, da dobimo dnevno mezdo, ki jo je prejel vajenec.

$48 \mathrm{Za}$ postopek reševanja tega problema gl. opombo k rešitvi naloge 5.

$49 \mathrm{Za}$ postopek reševanja tega problema gl. opombo k rešitvi naloge 5. Naloga, četudi šaljivo zastavljena, nam priča o ekonomskih realijah tistega časa. Zelo verjetno je bila navada Evropejcev na Vzhodu kupovati kamele, ki so jih potem uporabljali v Franciji ali drugje po Evropi za različne vrste transporta, na primer za transport vojaškega prateža. 


\section{Rešitev:}

Takrat ko je rekel: »O, da bi jih imel toliko,« je videl 36 ovac. Dvakrat toliko je 72, polovica od te polovice, to je od 36, pa je seveda 18. Če vzamemo polovico od te druge polovice, to je od 18 , dobimo 9 . Seštej torej $36+36$, da dobiš 72 . Tej vsoti dodaj 18 , da dobiš 90 . Nato pa številu 90 dodaj še 9 , da dobiš 99. Človek sam pa bo skupaj z ovcami stoti. ${ }^{50}$

\section{NALOGA O STAJI IN SVINJI}

Neki hišni gospodar je izdelal novo štirikotno ogrado, $v$ katero je postavil svinjo, ki je v sredini staje povrgla 7 prašičkov. Ti so skupaj z materjo, ki je osma, v vsakem kotu povrgli 7 novih. ${ }^{51}$ Nato pa so svinja in vsi njeni potomci v sredini staje povrgli še vsak po 7 prašičkov. Naj pove, kdor želi, koliko prašičev je bilo na koncu v staji skupaj z materami.

\section{Rešitev:}

V prvem kotenju, ki se je zgodilo v sredini staje, je nastalo 7 prašičkov, njihova mati pa je bila osma. Če torej pomnožimo $8 \times 8$, dobimo 64 . Toliko prašičkov je bilo v prvem kotu skupaj s svojimi materami. Nato zmnoži $8 \times 64$, da dobiš 512. Toliko prašičev je bilo skupaj z materami v drugem kotu. Dalje zmnoži $8 \times 512$, da dobiš 4096 . Toliko jih je bilo skupaj z materami v tretjem kotu. Če še to število pomnožiš z 8 , dobiš 32768 . Toliko jih je bilo skupaj z materami v četrtem kotu. Pomnoži pa nazadnje še $8 \times 32768$, da dobiš 262144 . Na toliko je namreč naraslo njihovo število, potem ko so v sredini staje povrgli še zadnjič. ${ }^{52}$

\section{NALOGA O STOPNIŠČU S STO STOPNICAMI}

Imamo stopnišče s 100 stopnicami. Na prvi stopnici je sedela ena golobica, na drugi sta sedeli dve, na tretji tri, na četrti štiri, na peti pet in tako naprej na vsaki stopnici vse do stote. Naj pove, kdor more, koliko je bilo vseh golobic.

\section{Rešitev:}

Štej takole: Vzemi golobico, ki sedi na prvi stopnici in ji prištej 99 golobic, ki skupaj sedijo na devetindevetdeseti stopnici, da jih bo skupaj 100. Na enak način združi drugo stopnico z osemindevetdeseto in dobil boš ravno tako 100 . Tako združi po eno stopnico od zgornjih z eno od spodnjih in vsota golobic, ki sedijo na njih bo vselej 100. Petdeseta stopnica pa je sama zase in neodvisna, saj je brez para. Prav tako bo sama ostala stota stopnica. Seštej torej vse skupaj in dobil boš 5050 golobic. $^{53}$

50 Gre za linearni problem $\mathrm{z}$ eno neznanko, ki ga rešimo $\mathrm{z}$ enačbo $x+x+\frac{1}{2} x+\frac{1}{4} x+1=100$, pri čemer je $\mathrm{x}$ število ovac, ki jih je človek videl na paši. Enačbo rešimo in dobimo pravilno rešitev $x=36$.

51 Mišljeno je, da vsi prašički, ki se rodijo iz mame in vsakega mladička v vsakem kotu skotijo po 7 novih prašičkov, kar ni jasno iz navodila, ampak šele iz rešitve.

52 Kot pri reševanju naloge 13 mora reševalec tudi tukaj računati potence nekega števila, $\mathrm{v}$ tem primeru števila 8 . Vendar pa, za razliko od naloge 13 , tukaj ne gre za duplatio oziroma za geometrijsko vrsto, saj ne iščemo vsote geometrijskega zaporedja, ampak samo njegov zadnji člen. Gre za geometrijsko zaporedje $8,8^{2}, 8^{3}, \ldots, 8^{6}$, pri katerem iščemo vrednost zadnjega člena: $8^{6}=262144$.

53 Pri tej nalogi je poleg same rešitve izjemoma podan tudi postopek za izračun vrednosti 


\section{NALOGA O PRAŠIČIH}

Neki človek je imel 300 prašičev. Ukazal pa je v treh dneh zaklati vse, in sicer tako, da se vsak dan zakolje liho število prašičev. (Podobno bi bilo s 30 prašiči.) Pa naj pove, kdor more, koliko prašičev od 300 (in od 30) je treba zaklati vsak dan. [Ta naloga je nerešljiva in je sestavljena za oštevanje.]

\section{Rešitev:}

Glej izmišljijo, ki je ni mogoče rešiti, namreč da bi v treh dneh zaklal 300 (ali 30) prašičev, in sicer vsak dan liho število! Ta izmišljija je namenjena samo oštevanju dečkov. ${ }^{54}$

\section{NALOGA O DEČKOVEM POZDRAVU OČETU}

Neki deček je pozdravil očeta rekoč: »Pozdravljen, oče!« Ta mu odvrne: »Pozdravljen, sin, da bi živel še enkrat toliko, kolikor si že preživel, ta podvojena leta pa potrojil in vzel še eno od mojih let, tako da boš imel 100 let.« Naj pove, kdor more, koliko je bil deček takrat star.

\section{Rešitev:}

Deček je bil star 16 let in 6 mesecev. Če to starost podvojišs, dobiš 33 let. Če 33 potrojiš, dobiš 99 . Če pa dodaš še eno očetovo leto, dobiš 100 let. $^{55}$

\section{NALOGA O GOLOBICI}

Golobica, ki je sedela na drevesu, je videla mimo leteti druge golobice in jim dejala: »O, da bi vas bilo dvakrat toliko in še tretjič toliko. Potem bi vas bilo skupaj z menoj 100.« Naj pove, kdor more, koliko golobic je letelo mimo.

Rešitev:

Bilo je 33 golobic, ki jih je najprej videla leteti. Dvakrat toliko je 66, če pa dodamo še tretjič toliko, dobimo 99. Dodaj še sedečo golobico in dobil boš $100 .^{56}$

\section{NALOGA O ČLOVEKU, KI JE NAŠEL MALHO}

Neki človek je hodil po cesti in našel malho, v kateri sta bila 2 talenta. ${ }^{57}$ Drugi, ki so bili priča njegovi najdbi, so mu dejali: »Brat, odstopi nam delež

aritmetične vrste $1+2+3+4+\ldots+99+100$. Postopek je naslednji: Z združitvijo $1+99,2+98,3+97, \ldots, 49+51$ dobimo 49 parov $\mathrm{z}$ vsoto 100 , ki jim je treba prišteti še petdeseteto in stoto stopnico, ki nimata para. Vse skupaj torej znese $49 \times 100+50+100=5050$

54 Problem je nerešljiv, saj je vsota treh lihih števil lahko samo liho število, števili 300 in 30 pa sta sodi.

55 Gre za linearni problem z eno neznanko, ki ga rešimo z enačbo $3(2 x)+1=100$, pri čemer je $\mathrm{x}$ dečkova starost v trenutku pozdrava. Enačbo rešimo in dobimo pravilno rešitev $x=16 \frac{1}{2}$, kar $\mathrm{v}$ koledarskem sistemu pomeni 16 let in 6 mesecev.

56 Nalogo se da zvesti na linearno enačbo $x+x+x+1=100$. Enačbo rešimo in dobimo pravilno rešitev $x=33$.

57 Talent je bila antična utežna mera, ki je imela v različnih obdobjih in okoljih različno vrednost. Italski talent je tehtal 100 rimskih funtov, vendar ta pretvorba ne velja za srednjeveško Francijo. Razmerja med merskimi enotami v Nalogah kažejo včasih odklon od tistih, ki so navedena v uvodu (prim. Merske enote), zato za pretvarjanje enot v tej nalogi glej Alkvinovo rešitev. Ko ugotovimo pretvorbe med enotami, ki nastopajo $\mathrm{v}$ nalogi, bomo problem $\mathrm{z}$ uporabo najosnovnejših računskih operacij zlahka rešili. 
svoje najdbe. « Toda najditelj je odkimal in jim ni hotel dati ničesar. Oni pa so se spravili nadenj, mu raztrgali malho in si razdelili denar, tako da je vsak dobil 50 zlatnikov. Ko je najditelj sprevidel, da se jim ne more več upirati, je iztegnil roko in pograbil 50 zlatnikov. Naj pove, kdor želi, koliko ljudi je bilo skupaj.

Rešitev:

$\mathrm{V}$ vsakem talentu je 75 funtov. V funtu pa je 72 zlatnikov. $75 \times 72$ znese 5400. Če to podvojimo, dobimo 10800 . V 10800 pa gre 216 petdesetic. 216 je bilo tudi ljudi.

\section{NALOGA O ŠKOFU, KI JE UKAZAL 12 HLEBCEV KRUHA RAZDELITI MED DUHOVŠČINO}

Neki škof je ukazal razdeliti 12 hlebcev kruha med duhovščino. Določil pa je tako: vsak duhovnik naj prejme po 2 hlebca, vsak diakon po polovico hlebca, vsak lektor pa po četrtino hlebca. Biti pa mora enako število hlebcev in oseb. Naj pove, kdor more, koliko duhovnikov, diakonov in lektorjev mora biti.

Rešitev:

$5 \times 2$ je 10, kar pomeni, da je 5 duhovnikov prejelo 10 hlebcev. En diakon je prejel polovico hlebca, med 6 lektorjev pa so razdelili vsega hlebec in pol. Seštej $5+1+6$, da dobiš 12 . Seštej še $10+\frac{1}{2}+1 \frac{1}{2}$, da dobiš 12 . Tako imamo 12 hlebcev in 12 oseb. Število oseb in hlebcev je torej enako. ${ }^{58}$

\section{NALOGA O ČLOVEKU, KI JE SREČAL ŠOLARJE}

Neki človek je srečal šolarje in jih vprašal: »Koliko vas je v šoli? « Eden izmed njih mu je odgovoril rekoč: »Ne želim ti povedati. Preštej nas, pomnoži nas z 2, nato pa še s 3. Kar dobiš, razdeli na četrtine. Če k eni četrtini dodaš mene, dobiš število 100.« Naj pove, kdor more, koliko je bilo šolarjev, ki so na začetku srečali sprehajalca na poti.

Rešitev:

$2 \times 33$ je 66 . Toliko je bilo šolarjev, ki so na začetku srečali sprehajalca. Če 66 pomnožiš z 2, dobiš 132 . To pomnoži s 3 , da dobiš 396 . Ena četrtina od tega števila je 99 . Če prišteješ dečka, ki je odgovoril, boš dobil $100 .^{59}$

\section{NALOGA O KOLARJIH}

Sedem kolarjev je izdelalo vsak po sedem koles. Naj pove, kdor želi, koliko vozov so lahko z njimi opremili.

Rešitev:

Zmnoži $7 \times 7$, da dobiš 49 . Toliko koles so izdelali. Če 12 pomnožiš s 4 , dobiš 48. Z 48 kolesi pa se da opremiti 12 vozov, pri čemer je eno kolo odveč.

58 Za postopek gl. opombo k rešitvi naloge 32. Naloga ima poleg rešitve, ki jo poda Alkvin, še eno rešitev: $x=5, y=1, z=6$ in $x=4, y=8, z=0$.

59 Gre za linearni problem $\mathrm{z}$ eno neznanko, ki ga rešimo $\mathrm{z}$ enačbo $\frac{3(x+x)}{4}+1=100$, pri čemer je $\mathrm{X}$ število šolarjev, ki so na začetku srečali sprehajalca. Enačbo rešimo in dobimo pravilno rešitev $x=66$. 


\section{NALOGA O VINU V POSODAH}

Naj pove, prosim, kdor zna, koliko poličev je v sto metrumih vina, in tudi koliko je v sto metrumih merov.

Rešitev:

$\mathrm{V}$ enem metrumu je 48 poličev. Pomnoži $100 \times 48$, da dobiš 4800 . Toliko je poličev. Podobno ima en metrum 288 merov. Pomnoži $100 \times 288$, da dobiš 28800. Toliko je merov. ${ }^{60}$

\section{NALOGA O VINU V POSODAH, KI JIH JE NEKI HIŠNI GOSPODAR RAZDELIL}

Neki hišni gospodar je na smrtni postelji svojim 4 sinovom zapustil 4 posode vina. $\mathrm{V}$ prvi posodi je bilo 40 mernikov, v drugi 30 mernikov, v tretji 20 mernikov in v četrti 10 mernikov vina. Poklical je oskrbnika svoje hiše in mu dejal: » Te štiri posode $\mathrm{z}$ vinom razdeli med moje štiri sinove, in sicer tako, da bo vsak dobil enako količino vina in enako število posod.« Naj pove, kdor razume, kako je treba deliti, da vsi 4 sinovi prejmejo enak delež od dediščine.

Rešitev:

$\mathrm{V}$ prvi posodi je torej bilo 40 mernikov, v drugi 30 mernikov, v tretji 20 mernikov in v četrti 10 mernikov vina. Seštej torej $40+30+20+10$, da dobiš 100. Nato dobljeno število razdeli na četrtine. Ena četrtina od 100 je namreč 25, število, ki pomnoženo z 2 da 50 . Vsakemu sinu je torej pripadel delež 25 mernikov vina, po 2 sinova pa sta si razdelila 50 mernikov. V prvi posodi je 40 mernikov, v četrti pa 10 mernikov. Če ju sešteješ, dobiš 50 mernikov. To količino boš razdelil med 2 sinova. Na enak način seštej 30 in 20 mernikov, ki so bili v drugi in tretji posodi, da dobiš 50 mernikov, ki jih boš enako kakor zgoraj razdelil med 2 sinova. Tako bo vsak imel 25 mernikov. Če boš storil tako, bo delitev med sinove pravična tako $\mathrm{v}$ vinu kot $\mathrm{v}$ posodah. ${ }^{61}$

\section{NALOGA O HIŠNEM GOSPODARJU}

Neki hišni gospodar je ukazal pretovoriti 90 mernikov žita $\mathrm{z}$ ene svoje posesti na drugo, ki je od prve oddaljena 30 lig. To pa je želel opraviti tako, da bi bilo vse žito prepeljano na eni kameli v treh prevozih in da bi bilo v vsakem prevozu pretovorjenih 30 mernikov žita. Kamela pa vsako prehojeno ligo poje mernik žita. Naj pove, kdor želi, koliko mernikov je preostalo.

Rešitev:

$\mathrm{V}$ prvem prevozu je kamela 30 mernikov nesla 20 lig poti in pojedla vsako ligo po en mernik, to je 20 mernikov. Ostalo je 10 mernikov. V drugem

6o Gre za preprost problem pretvarjanja med prostorninskimi merskimi enotami, in sicer med metrumi, poliči in meri. Alkvin $\mathrm{v}$ rešitvi poda pretvorbe med temi enotami ( 1 metrum $=48$ poličev, 1 metrum $=288$ merov, 1 polič $=6$ merov), ki pa so podane tudi v predgovoru (gl. Merske enote). 1 mer je torej približno enak enemu decilitru oziroma eni merici vina.

61 Gre za enak način reševanja kot pri nalogi 12, le da je tukaj rešitev na račun odvečnih podatkov $\mathrm{v}$ enem delu, v drugem delu nepopolna. Avtor namreč po tem, ko je že navedel količino vina, ki jo mora dobiti vsak od štirih sinov $\left(\frac{100}{4}=25\right)$, nadaljuje $\mathrm{z}$ razreševanjem problema delitve vina na drug, manj intuitiven način, ne navede pa, da je treba vsakemu sinu dodeliti po eno posodo in kako opraviti prelivanje. 
prevozu je prenesla 30 mernikov, od teh pojedla 20 in ostalo je 10 mernikov. $\mathrm{V}$ tretjem prevozu je naredila enako: prenesla je 30 mernikov, od teh pojedla 20 in ostalo je 10 mernikov. Preostalo je še 30 mernikov in še 10 lig poti. $\mathrm{V}$ četrtem prevozu je domov prenesla 30 mernikov, od teh pa jih je na poti pojedla 10, tako da je ostalo vsega 20 mernikov žita. ${ }^{62}$

\section{NALOGA O PREDSTOJNIKU SAMOSTANA Z 12 MENIHI}

Neki predstojnik samostana je imel pod okriljem 12 menihov. Poklical je oskrbnika svoje hiše, mu dal 204 jajca in mu velel, naj da vsakemu menihu enak delež jajc. Določil pa je tako: med 5 duhovnikov naj razdeli 85 jajc, med 4 diakone 68 jajc, med 3 lektorje pa 51 jajc. Naj pove, kdor more, koliko jajc je dobil vsak od njih, tako da ni nihče dobil niti preveč niti premalo, ampak vsi, kot smo dejali zgoraj, enak delež. ${ }^{63}$

Rešitev:

204 razdeli na 12 delov. Ena dvanajstina števila 204 pa je 17, saj dobiš 204, če zmnožiš bodisi $12 \times 17$ bodisi $17 \times 12$. Število 17 dobiš tudi, če vzameš eno petino od 85 ali eno četrtino od 68 ali eno tretjino od 51 . Seštej torej $5+4+3$, da dobiš 12. Toliko je menihov. Seštej še $85+68+51$, da dobiš 204 . Toliko je jajc. Po razdelitvi na 12 enakih delov po 17 vsakemu menihu torej pripade 17 jajc.

62 Prebrisan načrt, po katerem kamela v prvem in drugem prevozu na dveh tretjinah poti tovor odloži in ga šele $\mathrm{v}$ zadnjem prevozu prenese do drugega posestva, omogoči, da na drugo posestvo pride 20 mernikov žita, čeprav na začetku izgleda, da bo morala kamela pojesti vseh 90 mernikov za skupaj 90 lig poti. Rešitev te naloge, ki je prva znana naloga tega tipa, je zanimiva in izvirna, toda tudi problematična: prvič, Alkvin v rešitvi kameli pripiše štiri prevoze namesto treh, kolikor jih je predpisanih v nalogi, čeprav je to, kar Alkvin imenuje četrti prevoz, v resnici samo nadaljevanje tretjega. Drugič, Alkvin očitno predpostavi, da mora kamela jesti samo, ko je otovorjena.

63 Najverjetneje je kak srednjeveški prepisovalec del rešitve naloge po pomoti vključil že v izjavo, saj ta vsebuje informacije, ki so očitno odvečne. 